\title{
Regionalism in Latin America. Navigating in the Fog
}

\author{
Alberto van Klaveren \\ University of Chile \\ avanklaveren@uchile.cl
}

The more recent waves of regionalism in Latin America have been associated, respectively, with structuralist, neoliberal and post-liberal economic and political experiments in the region. Structuralist regionalism was inaugurated in the 1950s and somehow survived until the 1970s; open regionalism followed in the 1980s and 1990s, and was replaced, to a certain extent, during the next decade by postliberal regionalism. However, the limits, if not demise, of post-liberal experiments in the most important economies of Latin America pose the question of the future of regionalism. In this changing situation, this paper explores several questions that rise about the future of regionalism in Latin America. Will regionalism hold sway in Latin America? Will present integration schemes continue in the region? Will new entities arise? Will there be a convergence in diversity between integration projects in Latin America? Will the new context of global uncertainties lead to a revival of regionalism?

Keywords: Latin America, Regionalism, Economic Integration

Research for this paper was funded by the Swiss State Secretariat for Economic Affairs under the SECO / WTI Academic Cooperation Project, based at the World Trade Institute of the University of Bern, Switzerland.

SECO working papers are preliminary documents posted on the WTI website (www.wti.org) and widely circulated to stimulate discussion and critical comment. These papers have not been formally edited. Citations should refer to a "SECO / WTI Academic Cooperation Project" paper with appropriate reference made to the author(s). 


\section{Regionalism in Latin America. Navigating in the Fog \\ Alberto van Klaveren \\ University of Chile}

The idea of Latin American regionalism can be traced back far in its history. In fact, regional integration in Latin America is an idea as old as the region's states themselves, and it has retained its status as a persistent feature of the international relations of Latin America, starting in the early nineteenth century. The struggle for independence in the early nineteenth century was waged under a sense of unity, leading afterwards to regional conferences and more or less elaborated plans for unity, either in exclusively Latin American formations, or in the context of Pan-Americanism, which included the United States. Simon Bolívar, José de San Martín, Andrés Bello, and other founding fathers and intellectuals played key roles in the struggle for independence and consolidation of the new countries, as well as in the efforts to create a league of Republics, with common political, defense and commercial institutions, including a supranational parliamentary assembly. Their visions never succeeded, but the idea of regional cooperation has survived until now. Integration efforts in Latin America have undergone numerous vicissitudes, each of them accompanied by fervent enthusiasm, only to backslide eventually with a long list of pledges to deeper integration remaining unfulfilled. Real progress in integration has remained elusive. After the Second World War, Latin American attempts at regionalism have been pursued through different waves, generally associated with specific economic and political models adopted by participating states. They have also tended to diverge across space, gradually giving birth to separate blocs and overlapping projects.

The more recent waves of regionalism in Latin America have been associated, respectively, with structuralist, neoliberal and post-liberal economic and political experiments in the region. Structuralist regionalism was inaugurated in the 1950s and somehow survived until the 1970s; open regionalism followed in the 1980s and 1990s, and was replaced, to a certain extent, during the next decade by post-liberal regionalism. However, the limits, if not demise, of post-liberal experiments in the most important economies of Latin America pose the question of the future of regionalism. In this changing situation, several questions arise. Will regionalism hold sway in Latin America? Will present integration schemes continue in the region? Will new entities arise? Will there be a convergence in diversity between integration projects in Latin America? Will the new context of global uncertainties lead to a revival of regionalism?

\section{Regionalism and Globalization}

Regionalism is generally accepted as an overarching concept. According to Nye, it can refer to, respectively, "the formation of interstate associations or groupings on the basis of regions; and in the doctrinal sense, the advocacy of such formations." ${ }^{\prime 1}$ is the expression of a regional consciousness that develops from a sense of identity of

\footnotetext{
${ }^{1}$ Joseph S. Nye, "Introduction," in International Regionalism: Readings, ed. Joseph S. Nye (Boston: Little, Brown and Company, 1968), vii.
} 
countries situated in geographical proximity, which induces them to cooperate to achieve common goals or to confront political, economic, strategic and other practical problems.

Regionalism has become an important feature of world politics in a multipolar international system, as demonstrated by the development of several regional cores in Europe, North America, Southeast Asia, Northeast Asia, Southern Africa, the Maghreb, the Gulf nations, etc. On the one hand, globalization is a major external driver for regionalism ${ }^{2}$ and on the other, regionalization is one of the fundamental dimensions of global restructuring. Peter Katzenstein, for instance, argues that we are approaching a "world of regions." 3 Similarly, Acharya refers to "the emerging regional architecture of world politics," and the construction of "regional worlds.",

Cantori and Spiegel ${ }^{6}$ identified the following characteristics of a region: geographical proximity, common bonds (historical, social, cultural, ethnic and linguistic), a sense of identity, and international interactions. Although Börzel ${ }^{7}$ argues strongly in favor of clearly differentiating between regional cooperation and regional integration, one might also conceptualize regional integration as a special type or subset - not necessarily the most frequent - of regional cooperation or regionalism. ${ }^{8}$

Regions are porous entities without well-defined boundaries. The relationship between Latin America and the Caribbean provides a good example of the porosity of regionalism. In some instances, both groupings are merged and act jointly, as in the United Nations, where they form the GRULAC (Group of Latin America and the Caribbean). However, when it comes to trade issues, the Caribbean countries form their own separate group, invoking the need for differentiated treatment. Adhesion to subregional groups can also lead to overlapping membership. Guyana and Suriname, for instance, were invited to join the Union of South American Nations (UNASUR), despite their traditional participation in Caribbean institutions and their scant links with most of the South American countries.

Most regions feature more than one regional organization. Often, these organizations are complementary and perform different functions. Regional organizations can also overlap, not only in their membership but also in their mandates.

\footnotetext{
2 Tanja A. Börzel, "Theorizing Regionalism," in The Oxford Handbook of Comparative Regionalism, eds. Tanja A. Börzel and Thomas Risse (Oxford University Press, 2016), 45.

${ }^{3}$ Peter J. Katzenstein, A World of Regions: Asia and Europe in the American Imperium (Ithaca NY: Cornell University Press, 2005).

${ }^{4}$ Amitav Acharya, "The Emerging Regional Architecture of World Politics," World Politics 59, no 4(2007): 629-652.

5 Amitav Acharya, “Global International Relations (IR) and Regional Worlds: A New Agenda for International Studies,” International Studies Quarterly 58, no 4 (2014): 647-659.

${ }^{6}$ Louis J. Cantori and Steven L. Spiegel, The International Politics of Regions: A Comparative Approach, (Englewood Cliffs, N.J.: Prentice-Hall, 1970), 6 \& 7.

${ }^{7}$ Tanja A. Börzel, "Comparative Regionalism: European Integration and beyond," in Handbook of International Relations, eds. Walter Carlsnaes, Thomas Risse and Beth. A. Simmons $2^{\text {nd }}$ Ed (London: Sage, 2013).

${ }^{8}$ Detlef Nolte, Latin America's New Regional Architecture: A Cooperative or Segmented Regional Governance Complex, EUI Working Paper, RSCAS 2014/89 (Florence: European University Institute/Robert Schuman Centre for Advanced Studies, 2014).
} 
Interregionalism can be considered as an additional step in the theorizing of regionalism. ${ }^{9}$ Another author highlights interregionalism as a consequence of the policy of the European Union (EU) of creating and relating to regions as preferred counterparts in the international system. ${ }^{10}$ European-Latin American relations provide an example of that policy, as well as of its limitations and problems, especially when there is an asymmetry between a highly regionalized partner, such as the EU, and a diverse and less structured counterpart, as is the case of Latin America in any of the regional formations through which it acts. ${ }^{11}$

One of the last steps in the theorization of regionalism is, somewhat paradoxically, transregionalism. ${ }^{12}$ The concept refers to relations which have a special density or singularity and which transcend regions. Normally, they are built on elements of likemindedness, as is the case in trans-Atlantic relations. They can also be built on cultural and historical bonds: the Commonwealth, Francophonie, and Ibero-American Community are typical examples. This is also a relevant category for Latin America, not only in the case of the Ibero-American Community, but also for those countries of the region which participate in Pacific Basin groupings like Asia Pacific Economic Cooperation (APEC).

\section{The persistence of the regionalist idea and its major trends}

Regional cooperation and integration in Latin America has historically meant two quite different things. In the first place, it has meant regional cooperation between the countries of Latin America itself. Multiple initiatives have been launched, and many organizations and schemes have been developed under this banner. The second form of regionalism covers the entire Western Hemisphere, in the form of Inter-Americanism or the Inter-American System. ${ }^{13}$ This brand of regionalism concentrated more on the political realm, and its development was largely sponsored by the United States through a long series of Pan-American conferences, held from 1889 onwards, with the objective of promoting hemisphere-wide regionalism through multilateral institutions addressing regional cooperation, trade, development, human rights, democracy, security and other concerns. After the Second World War, this form of regionalism was given an elaborate, formal and institutional structure in the Organization of American States (OAS) and its

\footnotetext{
${ }^{9}$ Heiner Hänggi, "Interregionalism as a Multifaceted Phenomenon: In Search of a Typology”, in Interregionalism and International Relations, eds. Heiner Hänggi, Ralf Roloff, and Jürgen Rüland (New York, NY: Routledge, 2006), 31-63.

${ }^{10}$ Björn Hettne, "Interregionalism in World Order: The Diverging EU and US Models," in European Union and New Regionalism. Regional Actors and Global Governance in a Post-Hegemonic Era ed. Mario Telò (Aldershot: Ashgate, 2007), 107-126.

${ }^{11}$ Alberto van Klaveren, "Las relaciones políticas europeo-latinoamericanas," Nueva Sociedad 189 (2004), 60. See also Wolf Grabendorff, “La asociación estratégica Unión Europea-América Latina: ¿unas relaciones birregionales con geometría variable?" Revista del Centro Andino de Estudios Internacionales 13 (2013): 155-161.

12 Andrea Ribeiro Hoffman, "Inter- and Transregionalism," in The Oxford Handbook of Comparative Regionalism, 600-618.

13 See Regionalism and Governance in the Americas, ed. Louise Fawcett and Mónica Serrano (London: Palgrave Macmillan, 2005); G. Pope Atkins, Encyclopedia of the Inter-American System (Westport CT: Greenwood Press, 1997); and Governing the Americas: Assessing Multilateral Institutions, eds. Gordon Mace, Jean-Philippe Thérien, and Paul Haslam (Boulder, CO: Lynne Rienner Publishers, 2007).
} 
related bodies. The OAS has served as an important forum for political and legal debates and agreements between the countries of the hemisphere, as attested by the accreditation of permanent ambassadors to the Organization, something that has not occurred on the same scale in the case of purely Latin American political international organizations. The OAS has also led to the creation of an Inter-American Commission of Human Rights (IACHR), with the objective of investigating human rights violations in the region and, subsequently, the Inter-American Court of Human Rights, which was founded to adjudicate cases involving the interpretation of the provisions of the American Convention of Human Rights, adopted in 1969, but not in force until 1978. Although several Latin American countries have voiced strong criticism against the operation of these bodies, there are no equivalent institutions at the purely Latin American level. In 2001, the countries of the hemisphere established an institutional mechanism for the defense of democracy, in the form of an Inter-American Democratic Charter, which has been applied in a rather selective manner, proving largely ineffective in some cases. In general, however, hemispheric formal institutions have been able to persist, despite sometimes stringent differences among its membership, recurrent challenges to its legitimacy, and the suspension of one of its founding members, Cuba, for almost five decades.

Hemispheric regionalism has also occasionally been aimed at economic relations. The North American Free Trade Agreement (NAFTA), signed by Canada, Mexico and the United States at the end of 1992, and which came into force at the beginning of 1994, was an expression of hemispheric regionalism, albeit limited to the three Northern countries, which were already linked through a process of previous de facto integration. The establishment of NAFTA held important implications for the other countries of Latin America. Immediately after its conclusion, several countries expressed their interest in negotiating free trade agreements with the United States, which in effect materialized in several cases in the ensuing decades. Moreover, at the Summit of the Americas, which took place in December 1994 in Miami, the leaders of the hemisphere agreed to establish a Free Trade Area of the Americas (FTAA) by the year 2005 at the latest, and to achieve 'concrete' progress in negotiations before the end of the century. However, the initiative missed the targeted deadline of 2005, met growing resistance from several key players in South America - as became evident in the fourth Summit of the Americas, held in Mar del Plata, Argentina - and was finally abandoned. In the end, instead of an all-encompassing hemispheric free trade area, a hub-and-spoke scheme developed in the form of several bilateral FTAs of Latin American countries or groupings with the United States.

It is difficult to find strong defenders of hemispheric regionalism in the public discourse of Latin American political leaders and representatives, that is, outside the same InterAmerican instances in which they regularly participate. Rather, Latin American countries tend to uphold publicly in the global fora the idea of regionalism in its first version, i.e., restricted to only Latin American nations. A recent study confirms the persistence of a rhetoric of commitment to regionalism in the annual speeches of Latin American leaders to the United Nations General Assembly, despite repeated setbacks 
and failures. ${ }^{14}$ This political discourse should not come as a surprise, considering that Latin America has always acted as a regional group in the United Nations. Also, in Latin American domestic audiences, references to regionalism tend to be restricted to cooperation and integration between Latin American countries, excluding the United States. In fact, in the political discourse of Latin American, regionalism is often seen as a means of containing the United States and strengthening the negotiation capabilities of the countries with the rest of the world.

Regionalism in Latin America has clearly been state-led, with lesser involvement of market and society actors. Although intra-Latin American investments have increased significantly, business has not played a leading role in the establishment and/or advocacy of integration institutions. Civil society has also remained rather passive, sometimes holding closer links with their European and North American counterparts than with their Latin American colleagues. Political parties have tended to follow the same pattern. Although some parties originally had a regional orientation, the strongest foreign links tend to be with European and North American parties or political foundations.

Latin America forms a regional subsystem within the global system and its component states share a sense of regional identity and are perceived as such by external actors. ${ }^{15}$ Accordingly, regional integration has never been eliminated from the foreign policy agenda of Latin America. Regional and sub-regional integration arrangements seem to be in permanent revision.

Multiple types of integration initiatives have been under consideration. At times, accords represented important rethinking about economic regionalism; they have also taken the shape of a complex picture of overlapping initiatives and memberships. Regional cooperation and integration has not only been aimed at the emergence or renewal of economic accords such as free trade or common market agreements. Latin American countries have also developed new forms of cooperation in areas as diverse as the development of physical infrastructure, confidence building measures, technological development, energy, prohibition of weapons of mass destruction, and foreign policy coordination. In some cases, cooperation in these fields has laid the basis for, or at least has contributed to, the rise of more ambitious schemes. For instance, Latin America was the first region in the world to adopt a Treaty for the Prohibition of Nuclear Weapons, known as the Tlatelolco Treaty. Whereas Antarctica had earlier been declared a nuclearweapon-free zone under the 1961 Antarctic Treaty, Latin America was the first the region to put in place such a ban over a vast and populated area. On the other hand, the nuclear accords between Argentina and Brazil, which started in the early 1980s, opened the way for the full adhesion of both regional powers to the Tlatelolco Treaty, and served as mutual confidence building measures which contributed to a profound change

\footnotetext{
${ }^{14}$ Nicole Jenne and Luis Schenoni, Latin American declaratory regionalism: An analysis of presidential discourse (1994-2014), EUI Working Paper RSCAS 2015/53 (Florence: European University Institute, 2015).

${ }^{15}$ G. Pope Atkins, Latin America in the International Political System. $2^{\text {nd }}$ ed. (Boulder: Westview, 1989).
} 
in bilateral relations between Brasilia and Buenos Aires, which in turn facilitated the establishment of the Common Market of the South (MERCOSUR) in 1991.

The recurrence of the regionalist idea explains the multiplicity of Latin American regional organizations. That situation is not exceptional, since most world regions feature more than one regional organization. Often, these organizations are complementary and perform different functions. Some are sub-organizations of other or wider-ranging regional organizations. However, in Latin America many regional organizations overlap with regard to their mandates and constituent members, and typically tend to follow stop-go cycles, usually surviving in weakened versions. The final picture in Latin America is that of the proliferation and overlapping of regional organizations, initiatives, and memberships.

\section{The first wave: between Structuralism and the European example}

The first modern expressions of regionalism in Latin America emerged after the Second World War, postulated and advanced mainly by the United Nations Economic Commission for Latin America (ECLA), which later included the newly independent Caribbean states. ECLA, which became a very influential economic think tank in the region, was heavily influenced by the structuralist tradition of economic development, pioneered by the Argentine economist, and first Secretary General of ECLA, Raúl Prebisch. It reflected the experience of the region, which during the interwar period had already suffered the full impact of the economic depression and which throughout history had endured recurrent terms of trade asymmetries. Although economic structuralism and dependency theory stem from different traditions and maintained important conceptual and analytical differences, they converged in their rejection of free trade economists, postulating that underdevelopment results from the structural dependency and the integration of the developing world in the world economy. The rich or central economies, and especially multinational corporations, were seen as the main agents preventing the development of endogenous industries in the South, transferring their profits to the North and exploiting cheap labor in the developing world. ${ }^{16}$ Even though most of the premises of dependency theory could not be confirmed empirically and were later disproved by the experience of economies in Asia, which were able to grow and develop despite rhetoric to the contrary, it constituted one of the few contributions of the developing world to international political economy. It also influenced policies in the field of international economic relations. From this perspective, the rationale of regional cooperation was not to be found in functional cooperation or the widening of the markets as they existed, but through the fostering of structural transformations and the creation of new productive capacities. ${ }^{17}$

\footnotetext{
${ }^{16}$ André Gunder Frank, Capitalism and Underdevelopment in Latin America (New York and London: Monthly Review Press, 1969); Orlando Caputo and Roberto Pizarro, Dependencia y Subdesarrollo (Santiago: Centro de Estudios Socio Económicos, Universidad de Chile, 1971); Dependency Theory. A Critical Assessment, ed. Dudley Seers (London: Frances Pinter, 1981).

${ }^{17}$ Fredrik Söderbaum, "Old, New and Comparative Regionalism”, in Fredrik Söderbaum, “Old, New, and Comparative Regionalism," in The Oxford Handbook of Comparative Regionalism, 24.
} 
Accordingly, regional economic cooperation and integration were seen as a means for economic development and autonomy. In practice, integration in Latin America was seen as a way to further the process of import-substitution industrialization in the region, providing sufficiently large markets to satisfy economies of scale. Moreover, in order to avoid fragmentation and duplication, countries would complement each other's industrial production through specialization. Non-reciprocity and preferential treatments were to be granted to the lesser developed or smaller countries within each scheme. Protective barriers were to be erected or maintained against non-regional competitors, giving regional or sub-regional products an advantage. Thus, during this first wave of economic regionalism Latin American countries did not adopt models of integration involving an across-the-board removal of barriers to intra-regional trade and did not favor market-based resource allocation. The result was an imperfectly managed trade regime, imperfect because its own rules were frequently overridden. Intra-regional trade concessions were limited and selective, so as to maintain protection for existing industries. In general, integration in Latin America was conceived of as an instrument of collective defense against external adversities. ${ }^{18}$

The drive for integration led to the establishment of the Latin American Free Trade Association (LAFTA) in 1960, the Central American Common Market (CACM) in the same year, the Andean Pact in 1969 and the Caribbean Community (CARICOM) in 1973. The rationale for these schemes was in all cases the extension of importsubstitution industrialization to larger markets than simply national ones. At the same time, these schemes were seen as means of strengthening the countries' bargaining power and autonomy vis-à-vis third parties, normally of the developed world.

In all cases, the objectives of the pacts in the trade area were not achieved. LAFTA, which originally proposed the establishment of a free-trade area and industrial planning between the largest economies of the region, moved slowly in the direction of simply promoting bilateral partial trade agreements until around 40 percent of intra-Latin American trade was eligible for preferential tariffs by the mid-1980s. ${ }^{19}$ LAFTA, which in fact never achieved something close to free trade in the region, was revamped in 1980, adopting the rather misleading title of Latin American Integration Association (LAIA), somehow implying that it was advancing to a next and more ambitious stage. Although the revamped organization has proven useful in providing a general legal framework for generally bilateral trade agreements between its member countries, it has remained very far from its stated objective.

Created at the same time as LAFTA, the CACM was initially a success story. It gradually eliminated trade barriers between its member states, actively promoted intraregional trade, and provided the impulse for the establishment of several Central

\footnotetext{
${ }^{18}$ Gert.Rosenthal, "Un informe crítico a 30 años de integración en América Latina," Nueva Sociedad 113 (1991): 60-65. See also Guillermo Perry, “América Latina: Integración Regional y Globalización," Pensamiento Iberoamericano 1 (2017): 130-139.

${ }^{19}$ Jean Grugel, "Latin America and the Remaking of the Americas," in Regionalism and World Order, eds. Andrew Gamble and Anthony Payne, (London: Macmillan Press, 1996), 135
} 
American institutions. However, this integration process stagnated due to regional political crises, including a short war between two member states in the late 60s, the Central American conflict of the 1970s and the 1980s, and recurrent political and economic crises in several of the involved countries. ${ }^{20}$ CARICOM, which was established in 1973 to transform the Caribbean Free Trade Association (CARIFTA) into a common market, was not very effective in promoting trade among its members, if only because the countries inside the Community continued to export a similar range of goods. ${ }^{21}$ However, beyond trade, CARICOM can be seen as a successful version of regionalism in Latin America. It has promoted strong cooperation among its members; it possesses a secretariat, which exercises leadership, and provides advise; it has developed a strong sense of identity between the English-speaking states of the Caribbean; it has adopted foreign policy common stances; and it has engaged in collective negotiations with external partners like the European Union. No other Latin American integration model exhibits a similar record.

In turn, the Andean Pact, created in 1969 by a group of members of LAIA that pretended to move faster towards integration, embraced the European institutional model. It established a Commission, a Council, a Parliament, and a Court of Justice, attempting to incorporate some form of supranationalism. However, as could be expected, several of these institutions resembled their European models only in form, and lacked real weight, providing an almost perfect example of what Thomas Risse identifies as the emulation of regional institutional design. ${ }^{22}$ The Andean Pact, later transformed into the Andean Community, provided for intra-regional trade liberalization, with a certain component of managed trade. It also included a sort of regional planning for the localization of nascent industries, protecting them from external competition, and it established a special common statute for foreign investment, which included restricted participation and quotas for foreign investors. In the end, Chile, one of the founding members, withdrew from the organization in 1976 as a consequence of the adoption of radical neoliberal policies under the Pinochet dictatorship. Many years later, Venezuela also left the Community, opting to join another subregional scheme, MERCOSUR. Even though Colombia and Peru continue as full members of the organization, they are placing more energy and hope in a newer integration project, the Pacific Alliance, which they founded together with Chile and Mexico in 2011.

MERCOSUR, the Southern Common Market, represents another experiment in subregional integration. It was founded in 1991 by Argentina, Brazil, Paraguay and Uruguay, to promote the "free movement of goods, services and factors of production between countries through, inter alia, the elimination of customs duties and non-tariff

\footnotetext{
${ }^{20}$ See Alfredo Guerra-Borges, "La integración latinoamericana, los primeros años,” in Integración Latinoamericana y Caribeña, eds. José Briceño Ruiz, Andrés Rivarola Puntigliano and Ángel M. Casas Gragea (México DF: Fondo de Cultura Económica, 2012), 197-212.

${ }^{21}$ Jean Grugel, "Latin America and the Remaking of the Americas," 136.

22 Thomas Risse, "The Diffusion of Regionalism," in The Oxford Handbook of Comparative Regionalism, 96-99.
} 
restrictions on the movement of goods, and any other equivalent measures.",23 MERCOSUR countries agreed to eliminate customs duties, implement a common external tariff on certain imports from outside the bloc, adopt a common trade policy toward third countries, and realize the free circulation of its citizens. Its long-term goal was to become a common market. ${ }^{24}$ However, in the end it did not follow a traditional model and turned out very different from many previous or contemporaneous experiences. Although it originally emerged as an expression of open regionalism, in practice it also adopted some elements of the structuralist tradition, including forms of managed trade, and maintaining considerable degrees of protectionism vis-à-vis third partners. ${ }^{25}$ Although it adopted an elaborate institutional framework, its dispute settlement procedures have not always been orthodox, including a preference for personal contacts between its highest authorities. ${ }^{26}$ Despite these limitations, MERCOSUR remains the most significant trading bloc in Latin America, and has achieved higher degrees of intra-regional trade than any other integration scheme. It has also achieved political significance, reflecting a profound change in the nature of the relations between Argentina and Brazil, the largest countries in South America, which until the 1970s were characterized by rivalry and mistrust.

\section{The second wave: Open Regionalism}

Integration efforts in Latin America in the 1990s contrasted sharply with past experiences, reflecting the drastic transformations of the development strategies on which they were based. They started to be considered as part of an offensive strategy to strengthen the insertion of the region in the world economy. The new approach was oriented towards an outward-looking, "extroverted" integration strategy, ${ }^{27}$ based on market-based resource allocation which had to stimulate competitiveness. Unlike previous experiences, integration was accompanied by unilateral trade liberalization and the opening of national economies. Thus, the new integration schemes were based on across-the-board and accelerated trade liberalization; reciprocity in the concession of preferences; the simultaneous search for special trade relations with third countries; institutional flexibility; and collective leadership by the governments involved rather than by autonomous technical secretariats. ${ }^{28}$ The movement towards these new forms of

\footnotetext{
${ }^{23}$ Article 1, Treaty Establishing a Common Market between the Argentine Republic, the Federal Republic of Brazil, the Republic of Paraguay and the Eastern Republic of Uruguay (MERCOSUR). http://www.sice.oas.org/trade/mrcsr/TreatyAsun_e.asp. Accessed 25 November 2017.

${ }^{24}$ Félix Peña, "The MERCOSUR and its Prospects: An Option for Competitive Insertion in the World Economy, " In Prospects for the Process of Sub-Regional Integration in Central and South America, ed. IRELA. Madrid: IRELA, 1992.

${ }^{25}$ For an analysis of the evolution of MERCOSUR, see Mercedes Botto, La integración regional en América Latina: ¿Quo Vadis? (Buenos Aires: Eudeba, 2015), and Juliana Peixoto Batista and Daniela Perrotta, "El Mercosur en el nuevo escenario político regional: más allá de la coyuntura," Revista Desafíos, no. 30, I, (2017): 91-134.

${ }^{26}$ Andrés Malamud, "Presidential Diplomacy and the Institutional Underpinnings of Mercosur.

An Empirical Examination," Latin American Research Review, 40, no. 1 (2005): 138-64.

${ }^{27}$ Ruth Zimmerling, Latin America's Future in World Trade: Regional versus World Market Integration. Report on the International Conference held on March 24th and 25th in Francfort/Main in cooperation with the City of Francfort/Main. (Frankfurt: Friedrich Ebert Stiftung, 1992), 10.

${ }^{28}$ Guillermo Ondarts, "La nueva integración," Integración Latinoamericana 175 (1992), 12.
} 
regionalism was identified as "open regionalism," adopting a loosely defined concept which was first used in the Asia Pacific area, especially at APEC meetings, and which was later adopted in Latin America, including ECLAC. ${ }^{29}$ This new wave led to the revitalization of sub-regional integration projects throughout Latin America, and was closely linked to policies of structural reform and the opening of the participating economies to international trade and investment, promoted by what was known as the "Washington Consensus", advocated by a series of institutions based in Washington and actively supported by the United States government. The new impulse expressed itself in projects for the creation of free trade zones and common markets within very short periods of time, aimed at the free circulation of goods, services, capital and persons, and, in a later stage, at the coordination of economic policies. These measures were adopted by traditional integration schemes such as the Andean Community and the Central American Common Market, and by newer initiatives such as MERCOSUR.

Regionalism -be it in its Latin American or hemispheric variants - was viewed in the 1990s as a pre-condition for securing effective competitiveness, improved positions in global markets and increased negotiating capacity in the field of international economic relations. Development options, which emphasized autarchy and national selfsufficiency, were discarded in almost all countries. Integration was viewed as a means to enhance the competitiveness of Latin American industries and services. Widened markets were also considered as more attractive to foreign partners and become effective instruments for competing for goods, services and capital in world markets.

The Central American Common Market (CACM) rapidly followed the new trend, facilitated by the end of the Central American conflict and the democratization processes which took place in the 1990s. The reduction of political tensions and the prospects for economic recovery in the area revived the regional institutions. In 1991, the five members of the renewed CACM and Panama established the System of Central American Integration (SICA), aimed at the establishment of a common market, the strengthening of the sub-regional institutions, and the adoption of a common financial and exchange system. There was no doubt that these steps reflected a strong commitment to regional cooperation and regional integration, but each country also took its own steps to preserve some of its priorities and establish special relations with its main foreign partners, especially the United States. This ambivalence was especially evident in the case of Costa Rica, which had more diversified and dynamic foreign trade than its neighbors. Moreover, important sectors in Costa Rica were fearful of linking their economic destiny to the rest of Central America too closely, because of the long record of political and economic instability that had affected the other countries. Panama's very open economy and its role as intermediary also placed it in a different position regarding an eventual common market. Central American exercises in regional variable geometry surpass those of any other integration process. Only a few member

\footnotetext{
${ }^{29}$ See Juan Alberto Fuentes, "El regionalismo abierto y la integración económica", Revista de la CEPAL 53, (1994): 81-89, and Economic Commission for Latin American and the Caribbean, Open regionalism in Latin America and the Caribbean: economic integration as a contribution to changing production patterns with social equity, (Santiago: CEPAL, 1994).
} 
states participate in the Customs Union, three are part of the so called Northern triangle (Guatemala, El Salvador and Honduras), six are part of the Central American Parliament as full members, and eight are part of SICA.

A similar ambiguity was present in the case of the Andean Community. Although at the onset of the 1990s its then five member countries targeted 1995 for the establishment of a free trade area, and 1997 for the implementation of a common market, the deadlines were not met. In 1992 Peru decided to suspend its membership in the five-nation pact, a decision which was maintained until 1994. On the other hand, several members initiated negotiations for their own bi- and trilateral free trade zones. Adding confusion to this already blurred sub-regional design, Venezuela left the Andean Community in 2006, arguing that it had decided to join MERCOSUR and declaring that the Community had become "mortally wounded" after Colombia and Peru had signed free trade agreements with the United States. ${ }^{30}$ On the other hand, Bolivia made clear its interest to join MERCOSUR in the face of its strong economic interdependence with Brazil and Argentina, but without leaving the Andean Community.

Open regionalism also adopted a hemispheric dimension. The "conversion" of the United States to the regional approach ${ }^{31}$ led to the creation of the North American Free Trade Agreement (NAFTA) and to the broader vision of hemispheric partnership outlined in the 1994 Summit of the Americas, which led to the proposal of a Free Trade Area of the Americas (FTAA). Before the 1990s, both notions would not only have been dismissed as implausible but would also have been rejected for different reasons in the United States and Canada, on one hand, and the Latin American countries, on the other.

NAFTA was not geared towards the establishment of a common market and was not intended to emulate any formal integration process. It did not pretend to become a customs union with a common external tariff; it did not cede sovereignty to common economic or political institutions; it did not contemplate the free movement of labor; it did not include common agricultural or social policies; and it did not establish special funds to rectify the imbalances between the United States and Canada, on the one hand, and what is essentially a developing country such as Mexico, on the other. However, it was evident that the three member countries of NAFTA were already linked through a process of de facto integration. The density of cross-border interdependence has created problems that demanded common management. Thus, the agreement was considered as a way to formalize, regulate and deepen an ongoing process.

Mexico's option for a Free Trade Agreement (FTA) with its North American neighbors represented a radical break from the past. Historically, the idea of integration with the United States had been discarded by Mexican political leaders and elites on nationalistic

\footnotetext{
30 "Venezuela sale de la CAN," BBC Mundo, 20 April 2006, http://news.bbc.co.uk/hi/spanish/latin_america/newsid_4924000/4924980.stm. Accessed 5 July 2017.

${ }^{31}$ Augusto de la Torre and Margaret R. Kelly, Regional Trade Arrangements (Washington DC: International Monetary Fund, Occasional Paper 93, 1992), 1.
} 
grounds. However, the new economic realities of the country led to a revision of this traditional position. In less than a decade, Mexico was transformed from a highly protected and state-centered economy into an open one. For its new strategy to succeed, access to the main world markets had to be secured. After an initial search for new partners, Mexico realized that its heavy reliance on the U.S. market was an inescapable reality. In that context, an FTA with the United States was seen as a guarantee for continued access to a market which at the time accounted for more than 70 percent of Mexican foreign trade, and as a powerful incentive for the attraction of new U.S. investments. ${ }^{32}$ Additionally, it was viewed as a means to provide external reinforcement for the policies adopted by past governments and ensure the continuation of those policies in the future.

The establishment of NAFTA held important implications for the other countries of Latin America. Immediately after its conclusion, several countries of the region expressed their interest in negotiating FTAs with the United States. Their reasons were, to a certain extent, similar to those of Mexico. They viewed this option as a guarantee for continuous and predictable access to the U.S. market and as an incentive for foreign investors, proceeding from either the United States or third countries interested in accessing that market. The option seemed more valuable in the context of growing perceptions about the inevitable breakup of the world economy into trading blocs and the threat of the resurgence of protectionism. At the same time, free trade agreements with the United States were seen as a kind of insurance against the reversal of open and market-oriented economic policies as well as authoritarian setbacks.

In this favorable context, all the countries of the Western Hemisphere, except Cuba, embarked on the negotiation of the FTAA, which was supposed to extend NAFTA to all of the Americas. The proposal for the FTAA had its roots in the Enterprise for the Americas Initiative, announced by U.S. President George H.W. Bush in 1990. Following the signing of NAFTA in 1992, the earlier proposal was renewed under the aegis of the President Bill Clinton administration at the 1994 Summit of the Americas in Miami. The FTAA negotiations were carried out under an agreed structure and timetable. The final phase of the negotiations was placed under the co-chairmanship of Brazil and the United States in 2002, with a view to concluding all negotiations by January 1, 2005, and implementing the agreement no later than December 2005. As many as ten cities in the Americas presented their candidacies to host the FTAA secretariat. However, the initiative met the growing opposition of a group of countries led by Venezuela, already under President Chávez, and was finally rejected when Argentina and Brazil joined the group of objectors. What survived was a hub-and-spoke network of bilateral FTAs between Latin American countries and the United States, which was inaugurated by Chile (2003), and followed by Peru (2009), Colombia (2012), the Central American countries, and the Dominican Republic (2006-2009). On the other

\footnotetext{
${ }^{32}$ Guadalupe González and Jorge Chabat, "Mexico's Hemispheric Options in the Post-Cold War Era," in Foreign Policy and Regionalism in the Americas, eds. Gordon Mace and Jean-Philippe Thérien (Boulder: Lynne Rienner. 1996): 40.
} 
hand, 17 smaller Caribbean countries were granted preferential access to the U.S. market through the Caribbean Basin Trade Partnership Act, adopted by the United States in 2000. The major exception to this trend is represented by the MERCOSUR countries, which discarded the option of a free trade agreement with the U.S., although all of them participated, with variable degrees of enthusiasm, in the FTAA. In contrast, MERCOSUR has been negotiating an Association Agreement which includes a free trade pillar with the European Union since 2000, but after 17 years negotiations are still ongoing.

\section{The third wave: Post-Liberal Regionalism}

Domestic political changes in several Latin American countries and the rejection of neoliberal policies as framed by the Washington consensus led to the adoption of what several authors identified as post-liberal regionalism. ${ }^{33}$ Its proponents saw this new form of regionalism as post-hegemonic, meaning the partial displacement of dominant forms of U.S.-led neoliberal governance. ${ }^{34}$ This wave gave rise to new initiatives, including the Bolivarian Alliance for the Peoples of our Americas (ALBA), the Union of South American Nations (UNASUR), and the Community of Latin American and Caribbean States (CELAC). What these initiatives had in common was their aim to prioritize political cooperation among like-minded Governments, to bolster the bargaining power of Latin America vis-à-vis its main external partners, and to speak with a common voice in the global arena. Trade, which had played an important role in traditional regionalism in Latin America, was relegated to a secondary role, if not directly eliminated from the new schemes. In addition, the new wave of regionalism not only excluded the United States and Canada, but was also presented as an alternative to hemispheric regionalism. The impact of post-liberal regionalism was also felt in some of the traditional integration schemes, especially MERCOSUR.

The most radical expression of post-liberal regionalism was ALBA, initially proposed by President Hugo Chavez of Venezuela in 2001, but which only materialized in 2004 when Presidents Fidel Castro and Hugo Chavez endorsed the first declaration of the new grouping. ALBA represented a radical, ideologically transformative project that attempted to extend Chávez's twenty-first century socialism into the pursuit of a regional integration scheme, in direct opposition to neoliberalism. Since its conception in 2004, it proposed an alternative model of development underpinned by new principles of solidarity and complementarities. It is based on two pillars: endogenous development and a new internationalism based on the rejection of capitalism and imperialism and the practice of multinational companies. Part of its attraction to the

\footnotetext{
${ }^{33}$ José Antonio Sanahuja, 'Del 'regionalismo abierto' al 'regionalismo post-liberal'. Crisis y cambio en la integración regional en América Latina," in Anuario de la Integración Regional de América Latina y el Gran Caribe 2008-2009, eds. Laneydi Martínez Alfonso, Lázaro Peña, Mariana Vázquez (Buenos Aires: Coordinadora Regional de Investigaciones Económicas y Sociales (CRIES), 2009): 11-54 and, of the same author, Post-Liberal Regionalism in South America: The Case of UNASUR. EUI Working Paper RSCAS 2012/05. (Florence: European University Institute, 2010).

${ }^{34}$ Pia Riggirozi and Diana Tussie, "The Rise of Post-Hegemonic Regionalism in Latin America," in, The Rise of Post-Hegemonic Regionalism: The Case of Latin America, eds. Pia Riggirozi and Diana Tussie (Dordrecht: Springer, 2012): 1-16.
} 
smaller economies derived not so much from its ideological overtones but from Venezuela's Petrocaribe program, which has given Caribbean states oil supplies under a flexible credit mechanism, allowing them to pay for each shipment partly through cash, financing at low interest rates, or through the purchase of goods. On the other hand, Cuba's relatively well-prepared professional resources provided another source of exchange within the grouping. Accordingly, Cuban doctors, teachers, sports trainers and military advisors are present in most of the other ALBA countries.

The creation of UNASUR was a more complex story. It was the result of a series of presidential summits initiated by Brazil in the year 2000, which responded to a new geopolitical concept developed by its diplomacy and policy advisors. ${ }^{35}$ If historically Latin American regionalism had encompassed all of the region, including South America, Central America, Mexico, and the Caribbean, gradually some analysts and practitioners developed the idea of a separation between the Northern part of Latin America, inevitably linked to the United States, and South America, which could aspire to greater autonomy and a more diversified global role. Accordingly, UNASUR, conceded a sort of "symbolic gravitas to South America as a viable geopolitical entity." 36 For some time, Latin America seemed to have been replaced by South America. If, traditionally, inter-regional presidential summits were held between all Latin American countries and for instance, the European Union or the United States and Canada, in the 2000s new inter-regional summits were held between only South America and, Africa or the Arab world.

Although the idea of a South American community initially reflected Brazil's own core interests and goals, its final structure was the result of a complex and long negotiation in which several other countries of the region left their footprint. On the one hand, Venezuela, Bolivia and Ecuador attempted to introduce some form of supranationalism as well as ALBA's principles and concepts in the new organization. On the other, Chile, Colombia, and Peru, sometimes aided by Argentine and Brazilian diplomats, tempered the enthusiasm of the proponents of supranationalism and enhanced traditional regional political cooperation within the new organization. ${ }^{37}$ In the end, UNASUR was established in 2008 and is in force since 2011. Its objective, as stated in Article 2 of its Constitutive Treaty, is "to set up, in a participatory, agreed manner, a space for integration and union among its peoples in the cultural, social, economic and political fields, prioritizing political dialogue, social policies, education, energy, infrastructure, financing and the environment, among others, with a view to eliminating socioeconomic inequality, in order to achieve social inclusion and citizen participation, strengthen democracy and reduce asymmetries within the framework of bolstering the sovereignty

\footnotetext{
${ }^{35}$ See Marco Aurelio García, "Dez Anos de Política Externa," in 10 Anos de Governos Pós-Neoliberais no Brasil: Lula e Dilma, ed. Emir Sader, (São Paulo, SP: Boitempo; Rio de Janeiro: FLACSO Brasil, 2013): 57-58, and Celso Amorin, Breves Narrativas Diplomáticas (Buenos Aires: Taeda, 2014): 99-112.

${ }^{36}$ Sean W. Burgess, Brazilian Foreign Policy after the Cold War (Gainesville: University Press of Florida, 2009), 59. See also, Carlos G. Poggio Teixeira, "Brazil and the Institutionalization of South America: From Hemispheric Estrangement to Cooperative Hegemony," Revista Brasileira de Política Internacional 54, no. 2, (2011): 189- 211.

${ }^{37}$ For the case of Chile, see Ángel Flishfisch, “Chile y América del Sur,” Estudios Internacionales, 168 (2011): 115-142.
} 
and independence of the States." 38 The omission of trade liberalization from the main objectives of UNASUR is not accidental, since UNASUR did not include a trade agenda.

As a new organization, UNASUR reinforced the overlapping of regional organizations in Latin America. Its entrance into a regional architecture already packed with institutions - such as OAS, MERCOSUR, the Andean Community, the Rio Group, or ALADI - generated doubts and some friction both between and within them. From the beginning UNASUR adopted a political profile. One of its first successes was mediation in an internal crisis in Bolivia in 2008. It also mediated to quell a police insurrection in Ecuador in 2010, and contributed to allay bilateral tensions between Colombia and Venezuela in the same year. It also established sectorial committees on a wide group of issues, ranging from the promotion of physical integration through transport, energy and communication networks, to public health, social and economic affairs and defense. The establishment of the South American Defense Council of UNASUR in 2008 was probably the most controversial among them, since it was seen by some of its proponents as a substitute for the old Inter-American Defense Board, traditionally dominated by the United States. In practice, its achievements have been rather modest, including some useful confidence-building measures, but staying far from its more ambitious goal of becoming a kind of South American collective security organ.

At the time of its creation, UNASUR was the product of a coalition of governments with ideological affinities. However, it has not been able to maintain the organization's momentum. New political leaders have refrained from visiting its dazzling headquarters, inaugurated with fanfare in 2014 next to the Middle of the World monument outside of Quito, Ecuador; presidential summits have been postponed; and member states have been unable to elect a new Secretary General to succeed former President Samper of Colombia, who despite his previous moderate political background became a promotor of the interests of radical ALBA countries within the organization.

The establishment of the Community of Latin American and Caribbean States (CELAC) in 2011 has also been identified with post-liberal regionalism, although it can be seen as the culmination of a series of initiatives of political regional cooperation initiated with the Contadora Group, launched in the early 1980s by Colombia, Mexico, Panama and Venezuela to deal with the Central American crisis, and which was continued and expanded by the Rio Group, created in 1986 to support democracy and political cooperation in the region. ${ }^{39}$ Its geographic scope is wider than UNASUR as it includes all Latin American and Caribbean countries. It has no permanent secretariat, functioning pro tempore, rotating presidencies amongst its member states. Its main goal was to assemble, for the first time, all 33 Latin American and Caribbean countries, which had not jointly met in other mechanisms without the presence of countries from outside the region. Its other objectives are cooperation for development and political dialogue. It

\footnotetext{
${ }^{38}$ South American Union of Nations. Constitutive Treaty. http://www.gsdrc.org/docs/open/regionalorganisations/unasur,\%202008,\%20establishing\%20treaty.pdf. Accessed on 25 November 2017.

${ }^{39}$ Alberto van Klaveren, "El Grupo de Río: diez años de cooperación política regional". In El Grupo de Río: un diálogo vigente, ed. Raúl Barrios (La Paz: Unidad de Análisis de Política Exterior, 1996), 1852012
} 
has promoted ministerial or high-level meetings on different issues relevant to the region, such as education, social development, culture, transportation, infrastructure and energy. As was the case of UNASUR, trade liberalization was left out of its agenda. In terms of political consultations, CELAC has issued statements on relevant matters of the international and regional agenda, and has served as a regional interlocutor for dialogues between Latin America with the rest of the world, maintaining mechanisms of political dialogue and cooperation and the European Union, China, Russia and India. CELAC assumed the regional interlocution role in the dialogue and cooperation mechanism between Latin America and the Caribbean and the European Union (EU), established in 1999. Although originally devoid from the more ideological overtones of UNASUR, CELAC is following a similar fate. It has been unable to cope with the last political crises in the region, and in 2017 it had to suspend its bi-annual summit with the EU due to internal irreconcilable differences among its members concerning the Venezuelan crisis.

MERCOSUR also embraced the momentum of post-liberal regionalism in Latin America. Although it never formally abjured from its initial trade liberalization orientation, which included universal, automatic, and linear removal of trade barriers, and the establishment of a free-trade area with elements of an incomplete customs union, ${ }^{40}$ during the Kirchner governments it tended to concentrate more on public policy packages and political issues. The political relaunching of MERCOSUR could compensate for its exhaustion in economic terms. Even though Brazil and Argentina, its major members, held similar views on the domestic model of economic development, this concurrence was not helpful for the recovery of the project. The agenda of 'productive integration' in Argentina, which was shared by Brazil, was often interpreted in Buenos Aires as legitimizing protective measures against Brazilian exports, ignoring MERCOSUR's trade rules. ${ }^{41}$

No issue reflected better the politicization of MERCOSUR during the post-liberal wave than the admission of Venezuela and the suspension of Paraguay. Venezuela applied for admission to MERCOSUR in 2006, without complying with the admittedly modest acquis communautaire of the entity. Although the Executives of the four founding members -Argentina, Brazil, Paraguay and Uruguay- supported the admission, the incorporation was blocked by the then opposition dominated Senate of Paraguay. After six years' standoff, Venezuelan membership was finally approved, as the suspension of Paraguay, whose President had been impeached and deposed, removed the remaining legal obstacle. However, in 2017, political changes in Argentina and Brazil, and the readmission of Paraguay as a full member of MERCOSUR, now led to the suspension of Venezuela from the organization on the grounds that its democratic order had been

\footnotetext{
${ }^{40}$ Gian Luca Gardini, "Unity and Diversity in Latin American Visions of Regional Integration". In: Latin American Foreign Policies. Between Ideology and Pragmatism, ed. Gian Luca Gardini and Peter Lambert (New York: Palgrave Macmillan, 2011), 237.

${ }^{41}$ Roberto Russell and Juan Gabriel Tokatlian, "Argentina and the Rise of Brazil," in Foreign Policy Responses to Brazil. Balancing Power in Emerging States, eds. Gian Luca Gardini and Maria Hermínia Tavares de Almeida, (London: Palgrave Macmillan, 2016), 66.
} 
ruptured. ${ }^{42}$ In any case, for an economy as uncompetitive as that of Venezuela, the rationale for belonging to the bloc was not related to trade or other economic interests but to the international legitimization of its revolutionary regime and to stave off perceived threats from the US. ${ }^{43}$ Although officially it is still negotiating its accession, Bolivia is a full member of MERCOSUR, yet it remains

a full member of the Andean Community and ALBA.

\section{The fourth wave: coping with diversity}

Post-liberal regionalism was not the only game in town in Latin America. In 2011, Chile, Colombia, Mexico and Peru established the Pacific Alliance, which was formalized by a Framework Agreement signed in Cerro Paranal, Chile, one year later. Its aims are to promote the "deep integration" of economies through the free movement of goods, services, capital and labor, and to strengthen ties with the world, and the AsiaPacific region in particular. The four members have moved swiftly. In 2013, they signed an agreement to abolish tariffs on $92 \%$ of merchandise trade, with the remainder to be eliminated by 2020. They have scrapped tourist visa requirements for each other's citizens, and have opened some shared embassies and trade promotion offices abroad. The project has also attracted considerable international interest, as demonstrated by the more than fifty countries, which have adopted observer status. Four of them -Australia, Canada, New Zealand and Singapore- have been invited to become Associated States, which implies negotiating a collective last generation free trade agreement with the Pacific Alliance.

The Pacific Alliance is not only geared towards deepening trade and market access, but is also committed to going a step further in areas as government procurement, innovation, foreign trade, "single-window", movement of people, and trade facilitation, among other areas. Three of the founding members participate in APEC and are currently part of the Trans-Pacific Partnership (TPP) initiative. As Leví Coral and Reggiardo $^{44}$ recall, the Pacific Alliance is a form of open regionalism that clearly differs from post-hegemonic/post-liberal regionalism. In fact, it can be seen as an effort of four like-minded countries to promote an alternative to post-liberal regionalism, and bringing back Mexico to the region, and especially to South America. In contrast to the reluctance of MERCOSUR to secure free trade agreements with its most relevant foreign partners, the four members of the Pacific Alliance have opted for a pragmatic relationship structured around bilateral PTAs with the US, the EU, and Asian countries. Despite the commonly held view that the Pacific Alliance is a counterweight to UNASUR or MERCOSUR, it has put the economy first and has been extremely careful to avoid any political statements.

\footnotetext{
42 "Venezuela suspended from South American trade bloc," Financial Times, 5 August 2017. https://www.ft.com/content/fe66fcd2-79fe-11e7-9108-edda0bcbc928. Accessed 15 November 2017. ${ }^{43}$ Andrés Malamud, Overlapping Regionalism, No Integration: Conceptual Issues and the Latin American Experiences, EUI Working Paper 20, Florence: European University Institute/Robert Schuman Centre for Advanced Studies, 2013, 8.

${ }^{44}$ Leví Coral, Michel and Giulliana Reggiardo. "La Alianza del Pacífico en el regionalismo sudamericano actual," Revista Mexicana de Política Exterior 106 (2016): 187-204.
} 
However, the Alliance also faces obstacles. Its members are separated by vast distances and poor communication and have relatively few economic links. Intra-group trade is modest, and slightly sinking. Even MERCOSUR's intra-block trade is more significant as a share of the group's total than that of the Alliance. The integration of its financial markets and stock exchange through the establishment of the Integrated Latin American Market (MILA) proved more difficult than was initially envisaged.

It is tempting to depict a scenario of confrontation and rivalry between the Pacific Alliance, seen as a comeback of open regionalism, and MERCOSUR, seen a sort of incarnation of post-liberal regionalism. For a while, the idea of an Atlantic-Pacific divide seemed a reality in Latin America. ${ }^{45}$ In terms of trade policies, there were grounds to sustain it, but in political and geopolitical terms, it was never a reality. Chile has maintained closer relations with Argentina, even under governments of diverging ideological orientations, than with any of its Pacific Alliance partners. Santiago was also unwilling to alter its traditional relations with Brazil, Paraguay, and Uruguay. Peru significantly strengthened its political and economic ties with Brazil at the time that it cofounded the Pacific Alliance. Although Mexico was excluded from several regional initiatives and resented Brazilian policies, especially under the Lula governments, ${ }^{46}$ both countries always found some means of accommodation, as demonstrated by their participation in the establishment of CELAC.

Furthermore, political changes in the region point to a more nuanced picture. MERCOSUR countries are implementing economic reforms, including privatizations, and measures to liberalize some sectors of its industry and to attract foreign investment, which bring them closer to the policies adopted by the Pacific Alliance. Argentina and Uruguay have already negotiated their own bilateral trade agreements with Chile in 2017, abandoning the idea of only holding negotiations with third countries together with their MERCOSUR partners. This does not mean that trade policies in Latin America will automatically converge, but at least there is a certain rapprochement between the most relevant subregional groupings.

It is against this background that in 2014 the government of Chile proposed the idea to hold an informative Ministerial Dialogue between members of the Pacific Alliance and MERCOSUR, as well as the hosting of a seminar of academics, businessmen, entrepreneurs and senior officials of the Pacific Alliance, MERCOSUR and other countries of the region, including Central America and the Caribbean. In the same spirit, ECLAC prepared a background report on the subject. ${ }^{47}$ The report demonstrated the density of the network of agreements and existing relations between the countries from the Alliance and MERCOSUR. It is a network that has intensified in recent decades, especially in some of its connections, such as those in bilateral trade between Chile, Peru and Colombia, on the one hand, and Brazil and Argentina, on the other. For

\footnotetext{
${ }^{45}$ Post-Hegemonic Regionalism in the Americas. Toward a Pacific-Atlantic Divide? eds. José BriceñoRuiz and Isidro Morales (London: Palgrave Macmillan, 2017).

${ }^{46}$ Ana Covarrubias, "Mexico's Response to the Rise of Brazil," in Foreign Policy Responses to Brazil. Balancing Power in Emerging States, 205.

${ }^{47}$ Comisión Económica para América Latina y El Caribe, La Alianza del Pacífico y el MERCOSUR. Hacia una Convergencia en la Diversidad (Santiago de Chile: CEPAL, 2014). http://repositorio.cepal.org/, Accessed 17 November 2017.
} 
example, the partial agreements signed between these countries, within the framework of the LAIA, and the relations between MERCOSUR and the Andean Community of Nations, have already produced a complete tariff reduction between Chile and MERCOSUR countries (100\%). The percentages are also high in the cases of Peru $(88 \%)$ and Colombia (90\%). Another relevant fact was that in 2013 intra-MERCOSUR trade represented $14 \%$ of the global trade of its member countries, while intra-Alliance trade represented only $3.5 \%$. In the first case, the percentages were more significant because they included trade in manufactured goods. In turn, exports of the Alliance countries to MERCOSUR were higher than intra-Alliance exports (in 2013, intraAlliance exports were US\$19,500 million whereas those destined to MERCOSUR totaled US $\$ 23,700$ million). Chile, Colombia and Mexico exported more to MERCOSUR than to the Alliance countries. Additionally, data on trade in services and investments -even if incomplete- reveals the intensity of the relations between the Pacific Alliance and MERCOSUR countries, especially with Argentina and Brazil. This data, together with the new political scenario in the region, reveals potential for a convergence between the two main integration schemes in Latin America. However, as was stated by Minister Heraldo Muñoz at the inauguration of the Ministerial Dialogue, convergence does not imply unifying the two integration schemes nor engaging in tariff negotiations. It does imply, however, recognizing and respecting the differences between the objectives and the methods of both schemes, and even between the trade and development strategies and policies of its member countries. ${ }^{48}$ Various issues have been identified as deserving priority action. The main ones were: physical connectivity; trade facilitation; value chains and SME participation in them; student exchanges, including reciprocal internships between companies; the development of tourism; diagnostic capabilities on global economic competition; innovation and scientific and technological development; and monitoring and participation in international trade negotiations, both at the global multilateral level and at the interregional level. As a qualified observer of the process remarked, "Perhaps the main challenge that was posed as a result of the Santiago de Chile Seminar is to devise and recognize the need to develop short agendas and road maps for the priority areas of future joint action between the members of the different integration schemes. It is a challenge that involves not only governments, but also business, labor and academic institutions. ${ }^{49}$ And, it may be added, the challenge is still present.

\section{Conclusions}

Economic integration theory tends to present the integration process as the passage from less intense or demanding forms of inter-governmental cooperation to the actual union

\footnotetext{
${ }^{48}$ Speech of the Foreign Minister of Chile, Heraldo Muñoz: "Diálogo sobre Integración Regional: Alianza del Pacífico y Mercosur," Santiago de Chile, 24 de noviembre de 2014. http://www.minrel.gob.cl/discurso-del-canciller-munoz-dialogo-sobre-integracion-regional/minrel/201503-09/163854.html. Accessed 22 November 2017.

${ }^{49}$ Félix Peña, "Regional integration in Latin America: the strategy of "convergence in diversity" and the relations between MERCOSUR and the Pacific Alliance." Paper presented at the Seminar "A New Atlantic Community: The European Union, the US and Latin America," Jean Monnet Chair/European Union Center, University of Miami, Miami, February 27, 2015, 11.
} 
of economies. The path towards economic union includes subsequent stages such as a free-trade area, a customs union, a common market, an economic community, and an economic and political Union. ${ }^{50}$ This rather linear approach is not applicable to Latin America. In fact, integration in Latin American presents a complex and disorderly pattern. The removal of barriers can be partial and incomplete. A customs union announced in a treaty or a formal declaration can turn out in something very different in reality. The adoption of successive integration instruments can be more nominal than real. Some partial agreements have proven to be more effective for the removal of barriers and the strengthening of mutual interdependence than elaborate common market structures. A free trade arrangement, to the extent that it includes across-theboard tariff reduction, can be more far-reaching than a process aimed at the formation of a common market. Informal integration, consisting of intense patterns of interaction which develop without the impetus of deliberate political decisions, is often more important than formal integration. If there is a Latin American equivalent of the East Asian manufacturing supply chain, it lies not within any of the Latin American integration schemes but in Mexico's de facto integration with the United States. It is not very realistic to see integration in the region as a progression along the continuum that extends from cooperation to full integration. Accordingly, integration alternatives in the region are not pursued in a deliberate sequence and do not necessarily represent steps that follow a logical order. The signing of an integration treaty does not establish integration. As an author recalls, "It only signifies a promise by the leaders of several states to engage in a particular course of action over a period of time towards the aim of tying the economies of their countries closer together. True integration is achieved through the implementation of this promise, which entails a lengthy process of establishing common rules, regulations, and policies. It is these rules, regulations, and policies, based either on specific treaty provisions or derived over time from the general principles and objectives written into integration treaties, which will translate the aspiration for regional prosperity into reality."

Börzel argues that an integration process "involves the setting up of supranational institutions to which political authority is delegated to make collective binding decisions." 52 If we apply this definition, there would be no example of a successful scheme in Latin America. However, if integration is synonymous with regionalism or regionalization, ${ }^{53}$ the picture that emerges is more nuanced. Despite all of its shortcomings, Latin America exhibits considerable degrees of "interaction between political units (subnational, national, or transnational) provided by actors sharing

\footnotetext{
${ }^{50}$ Balassa, Béla, "Towards a Theory of Economic Integration," in Regionalism, Vol. I, 1940s-1960s Classical Regional Integration, eds. Philippe De Lombaerde and Fredrik Söderbaum (London: Sage, 2013): 169-180.

${ }^{51}$ Walter Mattli, "Explaining Regional Integration Outcomes," in Regionalism, Vol. IV. Comparative Regionalism (2000-2010), 3.

52 Tanja A. Börzel, "Comparative Regionalism: European Integration and beyond," in Handbook of International Relations, 508.

${ }^{53}$ Philippe De Lombaerde, "Comparing Regionalisms: Methodological Aspects and Considerations," in The Ashgate Research Companion to Regionalisms, eds. Timothy M. Shaw, J. Andrew Grant and Scarlett Cornelissen (Farnham: Ashgate, 2011), 38.
} 
common ideas, setting objectives and defining methods to achieve them, and by so doing contributing to building a region." 54 Obviously, the concrete results of these interactions are less than satisfactory in the areas of economics and politics, but the intentions remain. Some authors have attempted to deal with this phenomenon through the concepts of cooperative or segmented regional governance. ${ }^{55}$ Present reality in Latin America seems closer to segmented regionalism. It is still not clear how the regional architecture will evolve and what the emergence of a multifaceted pattern of overlapping regional organizations and projects will imply. What seems clear is that in the future there will be new initiatives and new efforts to revamp existing schemes. The myth of Sisyphus comes to mind.

However, the institutional disorder of Latin American regionalism should not be confused with the absence of regional regimes in the area. In fact, Latin America shares common values and norms regarding peace and security, such as the peaceful settlement of disputes, nonintervention, and the prohibition of arms of mass destruction, which are comparable to other regions of the world. Additionally, it has adopted common norms for the protection of human rights, democracy and the rule of law. Although the latter have not always been respected in all of the countries, they still stand as the most elaborate regional regime in the developing world. Some of the regional regimes have emerged from existing regional institutions, as was the case of the human rights regime, developed within the Inter-American framework. Others have evolved from strong historical and legal traditions, as was the case of the peaceful settlement of disputes. Others were the result of ad hoc negotiations, as was the case in the prohibition of nuclear weapons through the Tlatelolco Treaty of 1967.

In sum, despite all of the confusion and limitations of Latin American regionalism, there is still a considerable degree of "regionness", which has led to a Latin American international society ruled by common norms and shared practices. The fact that no institution in the region has been capable of regulating and governing this regionness adds another complexity to the study of Latin American regionalism.

\footnotetext{
${ }^{54}$ Oliver Dabène, The Politics of regional Integration in Latin America (Basingstoke: Palgrave, 2009), 215.

${ }^{55}$ Detlef Nolte, Latin America's New Regional Architecture: A Cooperative or Segmented Regional Governance Complex.
} 